DOI https://doi.org/10.36059/978-966-397-143-8/38-58

\title{
MODERN STAGE OF RESEARCHES ON THE SPIRITUAL SONG HERITAGE OF THE UKRAINIAN BAROQUE ERA
}

\section{Medvedyk Yu.}

\section{INTRODUCTION}

The study of the history of Ukrainian spiritual song began at the end of the $19^{\text {th }}$ century. Initially, these songs were studied by historians of literature (Mykhailo Hrushevskyi, Ivan Franko, Vladimir Peretz, Volodymyr Hnatiuk, Yuliian Yavorskyi, etc.). Only from the 1920s to the 1930s, the musicologist interested in Ukrainian and Eastern Slavonic spiritual songs (Filaret Kolessa, Stiepan Smolienskii, Mykola Hrinchenko, Nikolai Findeizen, Borys Hrinchenko, etc.). During the period of atheism in the Soviet Union, spiritual songs were hardly studied. Only from the end of the 1980s, the scientific interest of both philologists and musicologists arouse to them again. Therefore, in this study, we pay our attention to the main works of this stage of the research.

There are some grounds to associate the beginning of the modern stage in the development of scientific thought about the history of the formation and the development of Ukrainian spiritual song of the $17^{\text {th }}-$ $18^{\text {th }}$ centuries with the publication of the article "Chants and psalms" by the Kyiv researcher Tamara Sheffer. The article is included in the sixvolume book "The History of Ukrainian Music", the issue of which is obliged to the researchers of the Maksym Rylskyi Institute of Art, Folklore Studies and Ethnography of the National Academy of Sciences of Ukraine. Until that time only Mykola Hrinchenko ("The History of Ukrainian Music", Kyiv, 1922) and Andrii Olkhovskyi ("Essays on the History of Ukrainian Music", Kyiv, 1941) paid attention to spiritual songs in Ukrainian fundamental scholarly publications.

In general, this is the overview article, in which the issues of historiography and musicological analysis of the selected songs were discussed. T. Sheffer superficially studied the prehistory of the appearance of the anthology about Ukrainian spiritual song entitled "Bohohlasnyk" (Book of Chants) (Pochaiv, 1790-1791) and his numerous reprints 
(Pochaiv, 1805, 1825, L'viv, 1850, 1888, Kyiv, 1892, Sankt-Petersburg, 1900, 1903, Grodno, 1914, Warsaw, 1935, Moscow, 2000, Köln-WeimarWien, 2016) ${ }^{1}$.

The researcher also mentioned a few words about some ancient books (compilations) of the $18^{\text {th }}$ century in the Pochaiv monastery with the texts of spiritual songs, in particular, "The Mount of Pochaiv" $\left(1742^{2}\right.$. It is important that T. Sheffer was the first among musicologists to draw attention to the Pochaiv songbook (1773) for the glory of the local miracleworking icon ${ }^{3}$. However, she did not mention the source of this information and where this songbook is now. Before T. Sheffer, it was referred to only by M. Vozniak (quite thoroughly about poetic texts) and I. Franko (superficially). Today, this unique first-notated songbook has been reprinted with the necessary comments and source-textual study ${ }^{4}$.

A significant part of the article of $\mathrm{T}$. Sheffer primarily concerns the songs from "Bohohlasnyk". The researcher did not succeed in making an anthology of something essentially new in comparison with her predecessors (Mykola Hrinchenko, Borys Kudryk, Andrii Olkhovskyi). Basically, Tamara Sheffer laid out the dissertation of Oleksandra ShreierTkachenko, which was written in 1947 ("Ukrainian Romance-Song in its Sources and Development").

In the same year with the research of T. Sheffer, an article about the Pochaiv "Bohohlasnyk" was published by a Warsaw Ukrainianist Olha Hnatiuk $^{5}$. The appearance of this paper, to some extent, signalized about a new direction of the research on the spiritual song heritage in

${ }^{1}$ Recently, this ancient book has been reprinted and accompanied by a monographic study by Jurij Medvedyk (Rothe H., Medvedyk J. Bogoglasnik. Pesni blagogovejnyja (1790/1791). Eine Sammlung geistliche Lieder aus Ukraine. Hg. von Hans Rothe in Zusammenarbeit mit Jurij Medvedyk. Köln; Weimar ;Wien : Böhlau Verlag, 2016. Band 1: Facsimile. 602 S. Köln; Weimar ;Wien : Böhlau Verlag, 2016. Band 2: Darstellung. 432 S.).

${ }^{2}$ Гора Почаєвска стопою и образом чудотворним Пресвятой Дъвы Богородици почтенна, всему миру свђтла и явна в обители Почаевской типом издана [...]. Почаїв : Друкарня Успенського монастиря, 1742. 102 с.

${ }^{3}$ Шеффер Т. В. Канти і псальми. Історія украӥнської музики : від найдавніших часів до середини XIX cm. Київ : Наукова думка, 1989. Т. I : С. 218.

${ }^{4}$ Пісні до Почаївської Богородиці : перевидання друку 1773 року / транскрипція, ком. і досл. Ю. Медведика. Львів : Місіонар 2000. 149 с. (Серія «Історія української музики» : вип. 6 : Джерела).

5 Гнатюк О. Сторінка 3 історії української духовної поезії - почаївський Богогласник. Варшавські украӥнознавчі записки. 1989. Зошит I. C. 121-133. 
modern literary criticism. The already mentioned article and subsequent paper $^{6}$, as well as the monograph ${ }^{7}$, are aimed at in-depth analysis of the poetic content of the songs, deep immersion in the biblical metaphorics, and apocryphal sources of the texts, etc. The paper of great importance was her considerable compilation with the Ukrainian spiritual song texts from Lemko region, which contains a source-textual study of local handwritten songbooks of the $18^{\text {th }}$ century, which have been preserved thanks to the archival institutions of Kyiv and L'viv ${ }^{8}$. Several such manuscripts have been preserved in Prague; however, the researcher did not take advantage of them.

The monograph of $\mathrm{O}$. Hnatiuk is a solid interdisciplinary research in literary history, with a clear emphasis on the methods of theoretical analysis that were not traditional for spiritual song texts; and systematically covers a range of issues. It is necessary to pay attention to the attempts to comprehend spiritual songs in a theological sense, from the intertextuality point of view, and in the plane of the rhetorical value of the texts. In general, O. Hnatiuk's paper, despite numerous inaccuracies of mainly factual character, and categorical and controversial conclusions, leads us to believe that it is the beginning of a new promising direction in the genre's studying, adopting the methods of rhetorical analysis and intertextuality.

A significant contribution to contemporary musicology and performance was the compilation of "Ukrainian Chants of the $17^{\text {th }}$ $18^{\text {th }}$ centuries" arranged by Liudmyla Ivchenko, based on archeographic searches in libraries and archives of Ukraine and Russia ${ }^{9}$. The publication consists mainly of secular texts, but many spiritual chants by Danylo Tuptalo (Demetrios of Rostov), Feofan Prokopovych, Yepifanii Slavynetskyi, and Tymofii Shcherbatskyi were also included. The reference information about each musical-poetic text is listed there and is rather carefully developed. As a result of fruitful studies of musical

${ }^{6}$ Гнатюк О. «Богогласник» як антологія духовної поезії XVII - XVIII століть. Записки Наукового товариства Шевченка. 1995. Т. ССХХІХ. С. 7-15.

7 Гнатюк О. Українська духовна бароккова пісня : монографія. Варшава-Київ : Перевал, 1994. 188 с.

${ }^{8}$ Барокові духовні пісні з рукописних співаників XVIII ст. Лемківщини / вступ, упоряд. і ком. О. Гнатюк. Львів : Місіонер, 2000. 334 с.

9 Український кант XVII - XVIII століть / Упоряд., вступ. ст. і прим. Л. Івченко. Київ: Музична Україна, 1990. 200 с. 
source, L. Ivchenko managed to prepare a number of the articles for publication, also touching various aspects of the interaction of Ukrainian and Russian chant art in the second half of the $17^{\text {th }}$ and $18^{\text {th }}$ centuries.

Despite the fact that at the end of the $19^{\text {th }}$ and the beginning of the $20^{\text {th }}$ centuries ethnographers and folklorists showed great interest in the works of itinerant lira and lute players, their repertoire was not well studied. Later, as S. Hrytsa rightly noticed, "for more than half a century, the deep layer of spiritual heritage, i.e., spiritual poems, psalms, prayer songs, was almost completely excluded from Ukrainian folklore and folklore studies under the conditions of the totalitarian regime" 10 , that is, the repertoire, which was constantly used by folk singers. Olena Bohdanova also emphasizes "At this time, when itinerant player art emerged as an object of scientific thought, an active tradition and its research were forced to stop at its culmination period of 'high science'. Because of new ideological foundations [...], their research was outlawed"11. Therefore, we have "a scanty amount of spiritual works with melodies recorded by famous interpreters of the folk epics [...]. Such unique, and now spiritual poems, psalms, works in which the folklore and Christian origins merged into one, remained on the sidelines"12. Consequently, published musical scores of spiritual songs from the itinerant player repertoire, which were recorded in various regions of Ukraine by Mykola Lysenko, Porfyrii Demutskyi, Oskar Kolberg, Omeljan Vitoshynskyi and others are so important nowadays. They reflect the ancient tradition of spiritual song and the realities of the socio-cultural and religious life of the second half of the $19^{\text {th }}$ and early $20^{\text {th }}$ centuries.

The arrangement of spiritual songs, which, became the part of the lirnyk repertoire (mainly in the $19^{\text {th }}$ century), has aroused an interest in many Ukrainian composers. However, these songs have not been completely studied until this day. In this context, attention is drawn to individual researches by Natalia Kalutska ${ }^{13}$, which deals not only with

10 Грица С. Псальми в репертуарі кобзаря (До 95-річчя від дня народження Георгія Ткаченка). Народна творчість та етнографія. 1993. № 4. С. 42.

11 Богданова О. Збірник Порфирія Демуцького «Ліра та ії мотиви» у контексті лірницької традиції. Українське музикознавство. 2001. Вип. 30. С. 116.

${ }_{12}$ Грица С. Псальми в репертуарі кобзаря, с. 45.

13 Калуцька Н. Драматургічні аспекти аранжування обрядового фольклору (канти і псальми О. Кошиця). Українське музикознавство. 2001. Вип. 30. С. 129-137. 
some of the arrangements of spiritual songs performed by Oleksandr Koshyts. Choral arrangements of spiritual songs have also become the subject of musicological researches by Halyna and Jurij Medvedyk $^{14}$, as well as by Bohdan Shkil'nyk ${ }^{15}$, Though, only the first steps have been done in evaluating this legacy, and we encounter confusion even at the level of the terminological apparatus.

During the 1990s, Lydiia Kornii repeatedly turned to the research of spiritual songs. Most completely they are studied in the context of the research of the Ukrainian school theater of the $17^{\text {th }}$ - the first half of the $18^{\text {th }}$ centuries. As a recognized specialist in the study of ancient Ukrainian music and this genre, L. Kornii claims that there is a close relationship between the spiritual music (monody, part song, spiritual chants) and the school theater at the subject-thematic level, as well as the typological unity of the development of spiritual-biblical thematic.

On the verge of the $19^{\text {th }}-20^{\text {th }}$ centuries Ivan Franko, Mykhailo Hrushevskyi, Vladimir Peretts, and other researchers pointed out that many songs of different content fell under the influences of theatrical performances, in particular of medieval drama. For example, the song "Do not Cry, Rachel...” is completely like a theatrical scene. The expressive dialogical nature of this musical-poetic composition is quite consonant with the universal human nature and, especially, the Christian principles of the dualism of the world. "Therefrom the opposition of God and the devil, the holy and sinful, good and evil, eternity and death, love and hate, etc. This is observed in the school drama [...], in the verbal texts of the spiritual chants," writes L. Kornii ${ }^{16}$.

14 Медведик Г., Медведик Ю. Обробка барокової духовної пісні як сфера зацікавлень українських композиторів «нової школи» української церковної музики першої третини XX століття (до навчального курсу «Хорознавство»). Актуальні проблеми історії, теорії та практики художньої культури: зб. наук. праџь. 2011. Вип. XXVIII. С. 232-239.

15 Шкільник Б. Джерела текстів та специфіка хорових обробок духовних пісень в інтерпретації Михайла Гайворонського (питання джерелознавства). Актуальні питання гуманітарних наук: міжвузівський зб. наук. пр. молодих вчених Дрогобиџького державного педагогічного університету імені Івана Франка. 2017. Вип. № 17. C. 257-262.

16 Корній Л. Українська шкільна драма і духовна музика XVII - XVIII ст. Європейське Відродження та украӥнська література XIV - XVIII cm. : зб. наук. пр. Київ : Наукова думка, 1993. С. 198. 
Certainly, one more L. Kornii's conclusion deserves attention. She writes 'tthe spiritual chants, recorded in the 'Bohohlasnyk', belong to the Baroque genre. However, during the $17^{\text {th }}-18^{\text {th }}$ centuries, there was the evolution of the spiritual chant, which is also reflected in the chant of the 'Bohohlasnyk'. In a number of chants, the features of classical stylistics are evident. This is noticeable in the chants, the melodies of which show features of functional harmony, as well as in the form of chants, the strophe of which has a clear structure with symmetrical forms ${ }^{17}$.

Recently, Olha Zosim deals with the influence of Western European spiritual song on Ukrainian creation. One of the results of this direction of the research became a small (preliminary) incipit-catalog of "texts of Ukrainian songs of Western European origin based on Ukrainian and Russian manuscripts of the $17^{\text {th }}-19^{\text {th }}$ centuries" ${ }^{\text {"18 }}$. Among other things, O. Zosim emphasizes that there is a problem, the essence of which is "the complete or partial absence of materials that would allow us to represent all the stages of the development of the national spiritual song, as well as to cover all the regions where it existed. The layer of spiritual songs of the $16^{\text {th }}$ century, cultivated in Protestant centers, can not be restored [...]. The repertoire of the $17^{\text {th }}$ century, preserved primarily in Russian manuscripts, makes it difficult to analyze the Ukrainian tradition of European songs adapting" "19. Indeed, all this, as well as the study of the genre itself, its origin, national and foreign influences, functioning in a coordinate system of national culture, education, and religion, poses a significant problem. For more than 150 years of the studying of Ukrainian spiritual songs, that stratum of culture is becoming more comprehensible in its various manifestations. However, there are still many unsolved issues regarding the study of musical-poetic spiritual works.

The newest important research of O. Zosim is her monograph "Eastern Slavonic spiritual Song: the sacred dimension", in which this layer of culture is analyzed in the context of "the category of sacrality as

17 Корній Л. Історія української музики. Київ - Харків - Нью-Йорк : Вид-во М. П. Коць, 1996. Ч. 2. С. 109.

18 Зосім О. Українська духовна пісня західноєвропейського походження XVII XX ст. (до проблеми інтерпретації джерел). Науковий вісник НМАУ ім. П. І. Чайковського. 2006. Вип. 41. Кн. 2. С. 196 - С. 205-207.

${ }_{19}^{19}$ Там само, с. 197. 
the basic layer of the culture of the New Age"20. This direction of research is important from the point of view of modern philological and musicological intertextual studies.

\section{Ukrainian and Eastern Slavonic Spiritual Songs as the Subjects of the Modern Studies by Western Slavists}

In the last decade of the previous century, an American researcher Olha Dolskaya showed an interest in the spiritual song (chant) works. She submitted the dissertation on early Russian chant art ("The Early Kant in Seventeenth-Century Russian Music"; Kansas, 1993), which developed in close relations with the Ukrainian creation and also completely published the materials of the songbook's manuscript of the ' 90 s of the $17^{\text {th }}$ century from the funds of the Moscow State Historical Museum (GIM, No. 1938). The publication includes all the material. Therefore, Ukrainian texts, which make up almost the main part of the compilation, are presented here in full. Musical-poetic texts of the compilation of Muz. 1938 is preceded by a comprehensive introductory article by Olga Dolskaya ${ }^{21}$, where the main range of problems in the research of early spiritual-song creation is briefly covered.

In addition, some aspects of the genesis of spiritual lyrics were superficially considered. The thesis that the sources of spiritual-song works are rooted in the penitential prayers of the $15^{\text {th }}-17^{\text {th }}$ centuries, in the chants of the sacral monody and in the national folklore is clearly observed. According to the researcher, all that mentioned became the grounds for the emergence of Baroque spiritual songs in the East Slavs. A special place in this context belongs to the penitential lyrics, which at an early stage naturally flowed into the system of values and musical expressiveness means of the spiritual-song and musical-poetic baroque works. An excellent example of such influence is the musical-poetic text "Az yesm drevo neplodno, Hospody ..." published in the dissertation, which is known as monodic penitential poetry and as a spiritual polyphonic

20 Зосім Східнослов'янська духовна пісенність: сакральний вимір : монографія. Київ : ДАКККіМ, 2017. С. 4.

21 Spiritual Songs in Seventeenth-Century Russia. Edition of the MS 1938 from Muzejnoe Sobranie of the State Historical Muzeum in Moscow (GIM) / Transcribed and Edited by O. Dolskaya / Editorial Note by H. Rothe. Köln; Weimar; Wien : Böhlau Verlag, 1996. 367 p. 
chant (chant) of the $17^{\text {th }}$ century based on the material of numerous songbooks of that time.

The worldview foundations of the secularization character of Western European origin gave the second breath to spiritual lyrics in the Eastern Slavonic territories. O. Dolskaya has a point in stating that musical-style innovations, which were borrowed from the Polish spiritual song culture, played the most important role in this process. This process is reflected in the repertoire of the compilation of Muz. 1938, where a third of the Polishlanguage texts were transcribed in Cyrillic, which was typical for Russian compilation of that time.

Researcher's conclusion that the Czech spiritual songs are "distant ancestors" of Ukrainian and Russian spiritual songs texts deserves attention. In the context of the "ancestors" O. Dolskaya had to emphasize both Latin and German influences, which are at the stage of the study, in particular due to Olha Zosim; however, they have not yet been completely analyzed. They certainly had their echoes in Ukraine and Belarus, and partly in Moskoviia. Not so "remoted", but much less noticeable in the processes of the development of the Ukrainian spiritual-song works were Slovak spiritual songs. Their influence is the most noticeable in the texts of Western Ukrainian spiritual songs, especially those, which were created in Transcarpathia and Lemko region, as evidenced by the numerous remained songbooks from those regions. Within different time, Jurij Medvedyk ${ }^{22}$, Peter Ženuuch ${ }^{23}$, Olha Hnatyuk ${ }^{24}$ wrote about it. Some of the texts that are

22 Медведик Ю. Деякі тенденції становлення і розвитку церковно-слов'янського пісенного репертуару в паралітургійній культурі Закарпаття та Східної Словаччини від середини XVII до початку XIX ст. Slovenská, latinská a cirkevnoslovanská náboženská tvorba 15. - 19. storočá. Bratislava : Vydavatel'ské družstvo Lúč, 2002. S. 422-440; see also: Медведик Ю. Духовнопісенна культура Мукачівської єпархії у дослідженнях Петера Женюха // Калофюvia: наук. зб. з історії церковної монодії та гимнографії. 2010. Ч. 5. C. 174-197.

23 Žeňuch P. Medzi Východom a Západom: byzantsko-slovanská tradicia, kultúra a jazyk na Východnom Slovensku: monografia. Bratislava: Veda, 2002. 288 s.; Kyrillische paraliturgische Lieder. Edition des handschriftlichen Liedguts im ehemaligen Bistum von Mukačevo im 18. und 19. Jahrhundert. Cyrilské paraliturgické piesne. Cyrilská rukopisná spevniková tvorba v bývalom Mukačevskom biskupstve v 18. - 19. storočí. Hg. Peter Žeňuch. Köln; Weimar; Wien : Böhlau Verlag, 2006. 982 S.

${ }^{24}$ Барокові духовні пісні з рукописних співаників XVIII ст. Лемківщини / вступ, упоряд. і ком. О. Гнатюк. Львів : Місіонер, 2000. 334 с. 
recorded in these songbooks are included in the Moscow compilation (Muz. 1938).

The researcher partially touched upon the problems of the performing of interpretation texts, taking into account that the songs of the songbook should be studied not only from the scientific point of view but can also be used in concert practice. As emphasized by O. Dolskaya, their melodic and poetic texts form a mutually complementary unity, a harmonious spiritualelegiac picture; and they are consonant with the worldview of the religious person of that time. According to the researcher's opinion, such type of music requires a leisurely pace of performance. Therefore, it is more important because we deal with the songs created mainly in the first half the middle of the $17^{\text {th }}$ century. That is to say, at the time when they were still largely inspired by the spirit of the penitential poetry, and the texts of the sacred monody.

The Ukrainian spiritual songs constitute the basis of the songbook Muz. 1938. Among them are the texts of the authorship of the prominent personalities of Orthodoxy - Ukrainian Jepifanii Slavynets'kyi and Danyl Tuptalo. In that songbook are included 19 songs by Y. Slavynetskyi, such well-known ones as "Blahaho Tsaria Maty, shcho ty maiem vozdaty...", "Bohorodytse, Tsarytse, Prechysta Vladychytse ...", "Vsederzhyteliu Khryste Bozhii syne...", "Divo sviataia, Divo prekrasnaia...", "Zvizda, yavliaiushchy solntsa...", "O Divytse Prechystaia...", "Ratui Mariie, ratui, pohybaiem...", “O presviataia Mariie Divytse...", "Chystaia Divo, Tsarytse...,"25 and others. One of the songs of the Moscow compilation by O. Dolskaya was mistakenly appropriated to Teofan Prokopovych ("Lykuite, tserkve vostochnyia chada..."). However, as we know, he was born only in 1681, when the songbook was being rewritten. In fact, this text belongs to Belarusian Simeon Polotskii. There are many other kants by this author in the compilation, the repertoire of which consists of 166 musical-poetic texts.

A comparative analysis of the repertoires of the most ancient Ukrainian and Russian songbooks provides a lot of valuable information. Nevertheless, it is still necessary to carry out a lot of source-textual

${ }^{25}$ Pozdneev A. Die geistlichen Lieder des Epifanij Slavineckij. Die Welt der Slaven. Wiesbaden, 1966. Vol. 3/4. S. 356-357. 
researches on musical-poetic texts of the Moscow manuscript songbooks of the late $17^{\text {th }}$ century, as well as Lemko's songbooks of the first third of the $18^{\text {th }}$ century, in which the repertoire of the Ukrainian spiritual-song works of the $17^{\text {th }}$ century is almost entirely represented. In general, the repertoires of Moscow and Lemko compilations are very similar in many aspects. The next stage of the research lies in drawing parallels with the Ukrainian Pochaiv ancient books of the last third of the $18^{\text {th }}$ century, as several dozen of spiritual songs from these songbooks were later included in these publications.

In 1999, Hans Rothe published the article about the influence of the Polish spiritual song on Ukrainian and Russian spiritual-song creation ${ }^{26}$. From the German point of view, some of the processes of formation and development of Eastern Slavonic spiritual-song culture can be analyzed from the position, which is to some extent different from Ukrainian or Russian one. The article is based on two main issues - a) the place of spiritual song in the formation of national identity, b) spiritual song as the subject of scientific research. In this paper, the researcher attempts, through the analysis of the spiritual-song works of the Eastern Slavs, to answer the question when the Ukrainian European nation was emerged. According to the researcher, it is the end of the $16^{\text {th }}$ century. However, he means the nation, but not the folk that existed before that time. Furthermore, the researcher notes about inseparable existence from the Belarusians. Both questions are debatable.

Consequently, through the fundamental study of the spiritual-song culture, H. Rothe sees the ways to study the works processes in Ukraine. To answer the posed questions, the scholar encourages his contemporaries to take a new step forward in order to overcome the considerable shortcomings in the study of the spiritual song of the Eastern Slavs, primarily Ukrainians and Russians. He fairly points out that the depth of source studies on these texts does not correspond to the proper level. First of all, too little information has been found about both the origin of the manuscripts and songs. In this $\mathrm{H}$. Roth is right, since as a result of

${ }^{26}$ Роте Г. Западная (польская) духовная песня на восточнославянской почве: опыт постановки задачи. Traduzione e rielaborazione nelle letterature di Polonia, Ucraina $e$ Russia XVI - XVIII secolo / A cura di G. Brogi Bercoff, M. Di Salvo e L. Marinelli. Redacione di M. Piacentini. Allessandria: Edizioni dell’Orso, 1999. P. 109-126. 
mentioned reasons often arises an arbitrary interpretation of controversial issues.

Concerning the current state of studying of the spiritual-song heritage, the German Slavist notes that at this stage "some Western researchers have resumed their work on searching for manuscripts", mentioning Rostyslav Radyshevs'kyi and the author of this dissertation. "It remains only to wait for what result they will come, how far they will stand back from the totally Ukrainian position and how comparative their analysis will be" ${ }^{27}$. However, it is clear that for Ukrainian researchers, the "Ukrainian position" is typical. In addition, it is inconceivable to study the national spiritual-song culture outside of the Central-Eastern European context. Providing an example, it is worth to mention one of the papers by R. Radyshevs'kyi, dedicated to the Ukrainian Baroque poetry in Polish language. Analyzing that works, in his papers "Roksolans'kyi Parnas" he published several songs by the famous Ukrainian Orthodox personality Yoanykii Galiatovs'kyi, which were first issued in Kyiv in $1672^{28}$. The importance of this find makes it possible to raise doubt about the fact that in Moscow songbooks of the late $17^{\text {th }}$ century were recorded almost 150 Polish spiritual songs. As we can notice, some of them are Ukrainian, although written in Polish. Probably, the list of Polish songs may still be reduced due to further studies, which are carried out nowadays by many researchers in various directions and different countries.

Besides Hans Rothe, from the beginning of the XXI century Dieter Stern ${ }^{29}$, Achim Rabus ${ }^{30}$ and Vladimir Nemann ${ }^{31}$ began to turn their attention to the Ukrainian and Eastern Slavonic spiritual-song creation.

${ }^{27}$ Роте Г. Западная (польская) духовная песня, с. 114.

${ }^{28}$ Roksolański Parnas: polskojęzyczna poezja ukraińska od końca XVI do początku XVIII wieku / Wybrał i opracował R. Radyszewśkyj. Kraków: Wyd-two Naukowe DWN, 1998. 408 s. (Antologia ; cz. II).

${ }^{29}$ Die Liederhandschrift F 19-233 (15) der Bibliothek der Litauischen Akademie der Wissenschaften / Eine kommentierte Edition von Dieter Hubert Stern. Köln; Weimar; Wien : Böhlau Verlag, 2000. 689 S.

${ }^{30}$ Rabus A. Die sprache ostslavischer geistlicher gesänge im kulturellen kontext: monographie. Fraiburg: Weicher Verlag, 2008. 401 S.

31 Neumann V. Polnische Kirchenlieder in Moskau am Ende des 17. Jahrhunderts. Kommentierte Textedition der Liederhandschrift Pogodin Nr. 1974 aus der russischen Nationalbibliothek: Monographie. Köln; Weimar; Wien : Böhlau Verlag, 2016. 548 S. 
First of all, let us give a general evaluation of D. Stern's research about the unique manuscript "Suprasl' Bohohlasnyk"*. D. Stern's research has a complex character, since, besides entirely literary and linguistic issues, some aspects of a culturological, theological, confessional nature are considered. The textological work on the songs of the songbook, a rich source base, and the publication of the songs, as well as their numerous variations, deserve special emphasis. In the study of "Suprasl' Bohohlasnyk", the Ukrainian origin of the record is the main topic of the research, even though its repertoire is enriched with Polish, Latin, as well as some Belarusian spiritual songs. Such a multilingual song repertoire was typical of the ancient cantionals and songbooks in East-Central Europe of the Renaissance and Baroque eras. It should be noted that on the basis of the analysis of the songs which glorifying icons, D. Stern localizes a number of texts about icons, according to their Ukrainian regional origin.

Other works of D. Stern, which dealt with the study of Eastern Slavonic spiritual song creation of the $17^{\text {th }}-18^{\text {th }}$ centuries, are also important in their content and problematics. In particular, one should briefly analyze the article about the spiritual verse "Pryimy mia, pustyny, yako maty chado svoie ...", which in the $17^{\text {th }}$ century develops into the genre of the spiritual song-kant ("O, prekrasnaia pustyny, pryimy, mia $\mathrm{k}$ svoiei hustyny..." $)^{32}$. In this source-textual study, D. Stern used a wide range of handwritten and printed sources of Russian, Ukrainian and Belarusian origin (more information on it in the third chapter of the dissertation). In general, it should be noted a thorough source study of all works on spiritual songs, written by D. Stern. One of the papers deals with the source-archeographical identification of Eastern - Slavonic's spiritualsong manuscripts of the $17^{\text {th }}-18^{\text {th }}$ centuries $^{33}$.

The source-oriented is another article of the German Slavist, which is devoted to the genealogy of spiritual song. In the article states: "Our information about the exact time and place of the creation of some songs is

${ }^{*}$ Suprasl City (Western Belarusian) is well-known for its prominent monastery.

32 Штерн Д. Похвала пустыни Иоасафа - замечание к истории духовной песни у восточных славян. Slovenská, latinská a cirkevnoslovanská náboženská tvorba 15. - 19. storočiá. Bratislava : Slavisticý cabinet SAV, S. 441-454.

${ }^{33}$ Stern D. Ostslavische Cantiones und Kantionale: Ursprung und Verbreitung. Sakrale Grundlagen slavischen Literaturen / Herausgegeben von Hans Rothe. München : Verlag Otto Sagner, 2002. S. 107-133. 
nebulous [...]. It is also unknown how the songs were handed on"34. Undoubtedly, all remarks are relevant, although they are utopian to some extent. It is hardly possible to solve all the problems completely, since the authentic (author's) texts are difficult to find. In most cases, it is almost unlikely due to the absence of the most ancient manuscripts. If to take into account the $18^{\text {th }}$ century, this problem is less complicated. However, optimistic predictions are rather impossible, even if we consider rare authorial compilations of Ukrainian spiritual songs. Their number is extremely few: the songbooks of Zakharii Dziubarevych, Ivan Pashkovs'kyi, and Dmytro Levkovs'kyi.

D. Stern and $\mathrm{H}$. Rothe rightly state that we require detailed incipit catalogs, comprehensive source and bibliographic references, published texts and their versions, complete issues of selected handwritten and printed compilations, etc. It has been worthwhile for a long time to publish the "Kamianka Bohohlasnyk"* of 1734, which "plays a key role in the history of the Ukrainian spiritual kant of the $18^{\text {th }}$ century" 35 . Finally, another D. Stern's thesis has to be quoted: "Kant [...] is an explicit product of the book culture" ${ }^{36}$, that is undoubtedly supported by H. Rothe: "spiritual songs belong to the so-called wandering literature" 37 .

It is gratifying that H. Rothe and D. Stern's researches are not single in their field. We can assume that among the representatives of German Slavists of the new generation will be researchers interested in the ancient Eastern Slavonic musical-poetic spiritual creation, in particular in Ukrainian. The fact that the studies of a young researcher Achim Rabus are of interest to both their problematics and their scientific level encourages our minds. A particular interest deserves his monograph ${ }^{38}$, which analyzes

34 Штерн Д. Духовный кант - возможности и границы его генеалогической реконструкции. Russica Romana. Pisa-Roma : Instituti editoriali e poligrafici internazionali, 2002. Vol. VIII. P. 231.

* Lemko Region (today - in Poland).

${ }^{35}$ Там само, с. 233.

${ }^{36}$ Штерн Д. Духовный кант - возможности и границы, с. 236.

37 Rothe H. Paraliturgische Lieder bei den Ostslaven, besonders Ukrainer (Östliche Liturgie und westliches Kirchenlied). Sprache und Literatur der Ukraine zwischen Ost und West / Hg. J. Besters-Dilger, M. Moser, S. Simonek. - Bern; Berlin; Bruxelles; Frankfurt am Main; New York; Wien : Peter Lang, 2000. S. 30.

${ }^{38}$ Rabus A. Die sprache ostslavischer geistlicher gesänge im kulturellen kontext: monographie. Fraiburg: Weicher Verlag, 2008. $401 \mathrm{~S}$. 
the language of Ukrainian spiritual songs, which are recorded in the songbook ASP-233 (Vasyl Stefanyk National Science Library). Such a thorough study of the poetic texts of spiritual songs was carried out for the first time. The Slovak slavist Peter Žeňuch actively works on the research of the ancient spiritual-song heritage. His research interest is the ancient spiritual-song creation of Eastern Slovakia, as well as the Transcarpathian region of Ukraine, the so-called historical Transcarpathia.

The most noticeable works of P. Žeňuch became his study on spiritual-song (paraliturgic) creation in the Eparchy of Mukachevo during the $18^{\text {th }}-19^{\text {th }}$ centuries $^{39}$. This large-scale edition includes almost 1000 pages, where published poetic texts and some of their variants, and 475 so-called "Cyrillic paraliturgical songs" (many of them are known from other publications and ancient books). In general, the edition consists of the following chapters: a preface and an introductory article with the paleographic, descriptions of 19 handwritten songbooks, which according to P. Žeňuch come from the Eparchy of Mukachevo (9-84), a bibliography (87-97), reference information on the handwritten songbooks and selected Pochaiv ancient books (99-102), short publishing notes (103-104), issues of poetic songs and their versions (105-966), the list of acrostics (967970), and the incipitarium (971-982).

The publication is preceded by a significant study about the development of the spiritual-song culture of the Eparchy of Mukachevo of the $18^{\text {th }}-19^{\text {th }}$ centuries. P. Žeňuch has contextually analyzed a number of important researches on the history of the development of the spiritual song, existed in Transcarpathia and Eastern Slovakia. Much attention was paid to the selected handwritten and printed Slovak, Czech and Polish cantionals, a part of which was later translated into Church Slavonic language and included into the local Transcarpathian repertoire. Concerning the 19 handwritten Cyrillic songbooks studied by P. Žeňuch, it should be noted that not all of them are Transcarpathian or Eastern Slovakian. In addition, the vast majority of them were introduced into scientific circulation in the first third of the $20^{\text {th }}$ century. For example,

39 Kyrillische paraliturgische Lieder. Edition des handschriftlichen Liedguts im ehemaligen Bistum von Mukačevo im 18. und 19. Jahrhundert. Cyrilské paraliturgické piesne. Cyrilská rukopisná spevniková tvorba v bývalom Mukačevskom biskupstve v 18. 19. storočí. / Hg. Peter Žeňuch. Köln; Weimar; Wien : Böhlau Verlag, 2006. 982 S. 
"Kamianka Bohohlasnyk" of 1734 derived from Lemko region, as well as the songbooks of the late $18^{\text {th }}$ century, which were compiled and rewritten by Ioan Besmenyk (from Florynka village). However, the conclusions of Ivan Franko, Oleksandra Hnatiuk and Diter Stern, as well as the author of this dissertation did not persuade P. Žeňuch in the mistaken (biased) opinion concerning the "Kamianka Bohohlasnyk" of 1734. There are also some false premises concerning the song about the Klokochiv Mother of God, which is the object of Ukrainian creation, glorifying icons of the second half of the $17^{\text {th }}$ century, but not the Eastern Slovak, as is stated in the Slovak Slavistic research of Mikhal Lacko ${ }^{40}$ and P. Žeňuch ${ }^{41}$.

Regarding published texts, it should be paid attention to the detailed study of manuscripts. This is thorough and complicated work, as the texts often have illegible handwriting, many mechanical damages to the paper, records, etc. It is gratifying that for the first time the part of the researcher's texts was printed primarily from the records of the "Kamianka Bohohlasnyk" of 1734, "Šariš Songbook" and the songbook of I. Besmenyk. In order to avoid any discrepancies, it is worth to emphasize that the last of the above-mentioned handwritten songbooks has been recently figured in scientific literature as the songbook of the late $18^{\text {th }}$ century from Florynka village (Lemko region).

Not so long ago, appeared another paper of the researcher, which refers to the discovered $18^{\text {th }}$-century "Šariš Songbook". P. Žeňuch thoroughly studied the manuscript, presented a detailed incipit list of texts, made an attempt to date the compilation, and carried out a culturallinguistic assessment, etc. It is important that the researcher published a number of texts of spiritual songs (including those from the Eastern Slovakian regions of Spiš, Šariš, and Lemko region), thus introducing many of them into scientific circulation for the first time. His numerous comments on the content of songs, their genesis, historical-cultural and theological contexts, the dating of the manuscript, and so on, deserve our respect. However, here, the researcher made many mistakes and has a biased attitude, etc. In particular, we cannot agree with the Slovak Slavist

${ }^{40}$ Lacko M. A historical song from Eastern Slovakia (The song about the Icon of Klokočov). Slovak Studies : Historica. Cleveland - Rome : Slovak Institute, 1969. P. 107112.

${ }^{41}$ Zeńuch P. Historicka piesń o Klokočove. Proglas. 1994. № 5. S. 1-2. 
that the manuscript was created at the beginning of the $18^{\text {th }}$ century. This compilation includes several handwritings from different decades of the $18^{\text {th }}$ century, which was rewritten in Transcarpathia and Eastern Slovakia.

The source analysis of the Slovak influence on the formation of the repertoire of "Šariš Songbook" 42 deserves attention. Therefore, P. Žeňuch conducted a comparative analysis of the texts of this manuscript with the related papers "Cantus Catholici" (Levoča, 1655) and "Cithara Sanctorum" (Trnava, 1637). It is important to state that the researcher thoroughly tried to differentiate Polish and Latin influences. We should turn our attention that P. Žeňuch mainly points out to the powerful Ukrainian influence on the formation of the repertoire of this songbook, since without the Ukrainian religious and secular songs his repertoire would be minor.

Historiography of Ukrainian musical-poetic spiritual creation of the $17^{\text {th }}-18^{\text {th }}$ centuries is quite extensive and rich in the actual material. There reflected different views on the genesis, evolution, style characteristics of the spiritual songs' genre, and so forth. However, as time goes by, not all of the above-mentioned studies correspond to the modern methodology and methods of the research of genre, the present view on the processes, which occurred in the Ukrainian Baroque musical culture. Many studies are outdated from the source-analysis point of view. Nevertheless, almost every research added something new to the completion of the compositional structure of the historiographic ensemble as an instrument for further studies on one of the leading genres of ancient Ukrainian culture.

\section{SUMMARY}

This study deals with the history of the Ukrainian and Eastern Slavonic spiritual songs of the Baroque era. The main attention is paid to a retrospective review of the study of this genre during the period from the 1990s until now. It is stated that in spite of the researchers' interest in spiritual songs from the end of the 19th century, their musical and poetic texts were not almost analyzed from the early 1930s. The main reason was that in the Soviet Union religious music was not studied for ideological

42 Žeňuch P. Znovuobjavený Šarišský spevník zo začiatku 18. storočia vo svetle etnicko-konfesionálnych pomerov v karpatskom priestore. Slavika Slovaca. Slavistica. R. 41. Č. 2. Bratislava, 2006. S. 136-169. 
antireligious causes. Therefore, the returning to modern studies is a very important objective of the research, because the spiritual songs are an integral part of the national cultures of Ukrainian and Eastern European peoples not only of the Baroque era but also nowadays. The Ukrainian and Eastern European texts are a combination of the hymnographic GreekByzantine sacral culture and the Western European Catholic-Protestant spiritual song works of the Renaissance - Baroque period. Consequently, not only Ukrainian, Russian, and Belarusian researchers study the history of spiritual songs, but also Western European ones. Among them are H. Rothe, D. Stern, A. Rabus, V. Neumann and others. In this research, we focus our attention to their important studies.

\section{REFERENCES}

1.Барокові духовні пісні 3 рукописних співаників XVIII ст. Лемківщини / вступ, упоряд. і ком. О. Гнатюк. Львів : Місіонер, 2000. $334 \mathrm{c}$.

2. Богданова О. Збірник Порфирія Демуцького «Ліра та іiі мотиви» у контексті лірницької традиції. Українське музикознавство. 2001. Вип. 30. С. 116-129.

3. Гнатюк О. «Богогласник» як антологія духовної поезії XVII XVIII століть // Записки Наукового товариства Шевченка. 1995. T. CCXXIX. C. 7-15.

4. Гнатюк О. Сторінка 3 історії української духовної поезії почаївський Богогласник. Варшавські украӥнознавчі записки. 1989. Зошит I. C. 121-133.

5. Гнатюк О. Українська духовна бароккова пісня : монографія. Варшава-Київ : Перевал, 1994. 188 с.

6. Гора Почаєвска стопою и образом чудотворним Пресвятой Дъвы Богородици почтенна, всему миру свђтла и явна в обители Почаевской типом издана [...]. Почаїв : Друкарня Успенського монастиря, 1742. 102 с.

7. Грица С. Псальми в репертуарі кобзаря (До 95-річчя від дня народження Георгія Ткаченка). Народна творчість та етнографія. 1993. № 4. C. 42-52.

8. Зосім О. Східнослов'янська духовна пісенність: сакральний вимір : монографія. Київ : ДАКККіМ, 2017. 328 с. 
9. Зосім О. Українська духовна пісня західноєвропейського походження XVII - XX ст. (до проблеми інтерпретації джерел). Науковий вісник НМАУ ім. П. І. Чайковського. Київ, 2006. Вип. 41. Кн. 2. С. 196-210.

10. Калуцька Н. Драматургічні аспекти аранжування обрядового фольклору (канти і псальми О. Кошиця). Украӥнське музикознавство. 2001. Вип. 30. С. 129-137.

11. Корній Л. Історія української музики. Київ - Харків - НьюЙорк : Вид-во М. П. Коць, 1998. Ч. 2. 388 с.

12. Корній Л. Українська шкільна драма i духовна музика XVII - XVIII ст. Свропейське Відродження та українська література XIV - XVIII cm. : зб. наук. пр. Київ : Наукова думка, 1993. 194-214.

13. Шкільник Б. Джерела текстів та специфіка хорових обробок духовних пісень в інтерпретації Михайла Гайворонського (питання джерелознавства). Актуальні питання гуманітарних наук: міжвузівський зб. наук. пр. молодих вчених ДДПУ імені Івана Франка. 2017. Вип. № 17. С. 257-262.

14. Медведик Г., Медведик Ю. Обробка барокової духовної пісні як сфера зацікавлень українських композиторів «нової школи» української церковної музики першої третини XX століття (до навчального курсу «Хорознавство»). Актуальні проблеми історії, теорії та практики художньої культури: зб. наук. пр. 2011. Вип. XXVIII. С. 232-239.

15. Медведик Ю. Деякі тенденції становлення i розвитку церковно-слов'янського пісенного репертуару в паралітургійній культурі Закарпаття та Східної Словаччини від середини XVII до початку XIX ст. Slovenská, latinská a cirkevnoslovanská náboženská tvorba 15. - 19. storočá. Bratislava : Vydavatel'ské družstvo Lúč, 2002. S. 422-440.

16. Медведик Ю. Духовнопісенна культура Мукачівської єпархії у дослідженнях Петера Женюха // Калофюvia: наук. зб. $з$ іст. церковної монодії та гимнографії. 2010. Ч. 5. С. 174-197.

17. Медведик Ю. Нижньо-Тварозький співаник середини 30-х років XVIII ст.: його місце в українській духовнокантовій культурі та рукописній традиції жанру / ed. J. Dorul'a. Slovensko- 
rusinsko-ukrajinské vzt'ahy od obrodenia po súčasnost'. Bratislava: Slavistický cabinet SAV 2000. S. 350-369.

18. Пісні до Почаївської Богородиці : перевидання друку 1773 року / транскрипція, ком. і досл. Ю. Медведика. Львів : Місіонар 2000. 149 с. (Серія «Історія української музики» : вип. 6 : Джерела).

19. Роте Г. Западная (польская) духовная песня на восточнославянской почве: опыт постановки задачи. Traduzione $e$ rielaborazione nelle letterature di Polonia, Ucraina e Russia XVI XVIII secolo / A cura di G. Brogi Bercoff, M. Di Salvo e L. Marinelli. Redacione di M. Piacentini. Allessandria: Edizioni dell'Orso, 1999. P. 109-126.

20. Український кант XVII - XVIII століть / Упоряд., вступ. ст. і прим. Л. Івченко. Київ: Музична Україна, 1990. 200 с.

21. Шеффер Т. В. Канти і псальми. Історія української музики : від найдавніших часів до середини XIX cm. Київ : Наукова думка, 1989. T. I : C. 217-231.

22. Шкільник Б. Джерела текстів та специфіка хорових обробок духовних пісень в інтерпретації Михайла Гайворонського (питання джерелознавства). Актуальні питання гуманітарних наук: міжвузівський зб. наук. пр. молодих вчених Дрогобицького державного педагогічного університету імені Івана Франка. 2017. Вип. № 17. С. 257-262.

23. Штерн Д. Духовный кант - возможности и границы его генеалогической реконструкции. Russica Romana. Pisa-Roma : Instituti editoriali e poligrafici internazionali, 2002. Vol. VIII. P. 231-237.

24. Штерн Д. Похвала пустыни Иоасафа - замечание к истории духовной песни у восточных славян. Slovenská, latinská a cirkevnoslovanská náboženská tvorba 15. - 19. storočiá. Bratislava: Slavisticý cabinet SAV. S. 441-454.

25. Die Liederhandschrift F 19-233 (15) der Bibliothek der Litauischen Akademie der Wissenschaften / Eine kommentierte Edition von Dieter Hubert Stern. Köln; Weimar; Wien : Böhlau Verlag, 2000. $689 \mathrm{~S}$.

26. Dolskaya-Ackerly O. The Early Kant in Seventeenth-Century Russian Music : Ph. D. Thesis. Kansas, 1993. 312 p. 
27. Kyrillische paraliturgische Lieder. Edition des handschriftlichen Liedguts im ehemaligen Bistum von Mukačevo im 18. und 19. Jahrhundert. Cyrilské paraliturgické piesne. Cyrilská rukopisná spevniková tvorba $\mathrm{v}$ bývalom Mukačevskom biskupstve $\mathrm{v} 18$. 19. storočí. / Hg. Peter Žeňuch. Köln; Weimar; Wien : Böhlau Verlag, 2006. $982 \mathrm{~S}$.

28. Lacko M. A historical song from Eastern Slovakia (The song about the Icon of Klokočov). Slovak Studies: Historica. Cleveland Rome : Slovak Institute, 1969. P. 107-112.

29. Neumann V. Polnische Kirchenlieder in Moskau am Ende des 17. Jahrhunderts. Kommentierte Textedition der Liederhandschrift Pogodin Nr. 1974 aus der russischen Nationalbibliothek: Monographie. Köln; Weimar; Wien : Böhlau Verlag, 2016. 548 S.

30. Pozdneev A. Die geistlichen Lieder des Epifanij Slavineckij. Die Welt der Slaven. Wiesbaden, 1966. Vol. 3/4. S. 356-357.

31. Rabus A. Die sprache ostslavischer geistlicher gesänge im kulturellen kontext: monographie. Fraiburg: Weicher Verlag, 2008. $401 \mathrm{~S}$.

32. Roksolański Parnas: polskojęzyczna poezja ukraińska od końca XVI do początku XVIII wieku / Wybrał i opracował R. Radyszewśkyj. Kraków: Wyd-two Naukowe DWN, 1998. 408 s. (Antologia ; cz. II).

33. Rothe H., Medvedyk J. Bogoglasnik. Pesni blagogovejnyja (1790/1791). Eine Sammlung geistliche Lieder aus Ukraine. Hg. von Hans Rothe in Zusammenarbeit mit Jurij Medvedyk. Köln; Weimar ; Wien : Böhlau Verlag, 2016. Band 1: Facsimile. 602 S. Köln; Weimar ; Wien : Böhlau Verlag, 2016. Band 2: Darstellung. 432 S.

34. Rothe H. Paraliturgische Lieder bei den Ostslaven, besonders Ukrainer (Östliche Liturgie und westliches Kirchenlied). Sprache und Literatur der Ukraine zwischen Ost und West / Hg. J. Besters-Dilger, M. Moser, S. Simonek. Bern; Berlin; Bruxelles; Frankfurt am Main; New York; Wien : Peter Lang, 2000. S. 17-31.

35. Spiritual Songs in Seventeenth-Century Russia. Edition of the MS 1938 from Muzejnoe Sobranie of the State Historical Muzeum in Moscow (GIM) / Transcribed and Edited by O. Dolskaya / Editorial Note by H. Rothe. Köln; Weimar; Wien : Böhlau Verlag, 1996. 367 p. 
36. Stern D. Ostslavische Cantiones und Kantionale: Ursprung und Verbreitung. Sakrale Grundlagen slavischen Literaturen / Herausgegeben von Hans Rothe. München : Verlag Otto Sagner, 2002. S. 107-133.

37. Zeńuch P. Historicka piesń o Klokočove. Proglas. 1994. № 5. S. 1-2.

38. Žeňuch P. Medzi Východom a Západom: byzantsko-slovanská tradicia, kultúra a jazyk na Východnom Slovensku: monografia. Bratislava : Veda, 2002. 288 s.

39. Žeňuch P. Znovuobjavený Šarišský spevník zo začiatku 18. storočia vo svetle etnicko-konfesionálnych pomerov v karpatskom priestore. Slavika Slovaca. Slavistica. R. 41. Č. 2. Bratislava, 2006. S. 136-169.

\section{Information about the author: Medvedyk Yu.}

Doctor of Arts, Professor, Department of Musicology and Art of Choral Conducting, Ivan Franko Lviv National University 19, Valova str., Lviv, 79008, Ukraine 